\title{
Techniques for determination of true-to-type date palm (Phoenix dactylifera L.) plants: A literature review
}

\author{
K. J. Kunert ${ }^{1}$, M. Baaziz ${ }^{2}$ and C. A. Cullis ${ }^{3}$ \\ ${ }^{1}$ Botany Department, Forestry and Agricultural Biotechnology Institute, University of \\ Pretoria, Pretoria 001, South Africa \\ ${ }^{2}$ BAP Laboratory, Cadi Ayyad University, Marrakech 40000, Morocco \\ ${ }^{3}$ Department of Biology, Case Western Reserve University, Cleveland, Ohio 44106, USA
}

\begin{abstract}
Production of date palm by in vitro techniques has been established in several commercial laboratories to produce large numbers of date palm plants at a competitive cost. In vitro propagation of plants requires that produced plants remain true-to-type as an important part of the quality assurance. With the advancement of biotechnology, several screening techniques for identification of true-totypeness on the protein and the DNA levels have been developed, which might be applicable for identification of cultivars and detection of plant off-types. The advantages and disadvantages of these protein and DNA-based techniques are presented and strategies of their possible use as a quality assurance tool into commercial plant micropropagation laboratories are discussed.
\end{abstract}

Key Words: date palm, DNA markers, isozymes, somatic embryogenesis, in vitro propagation.

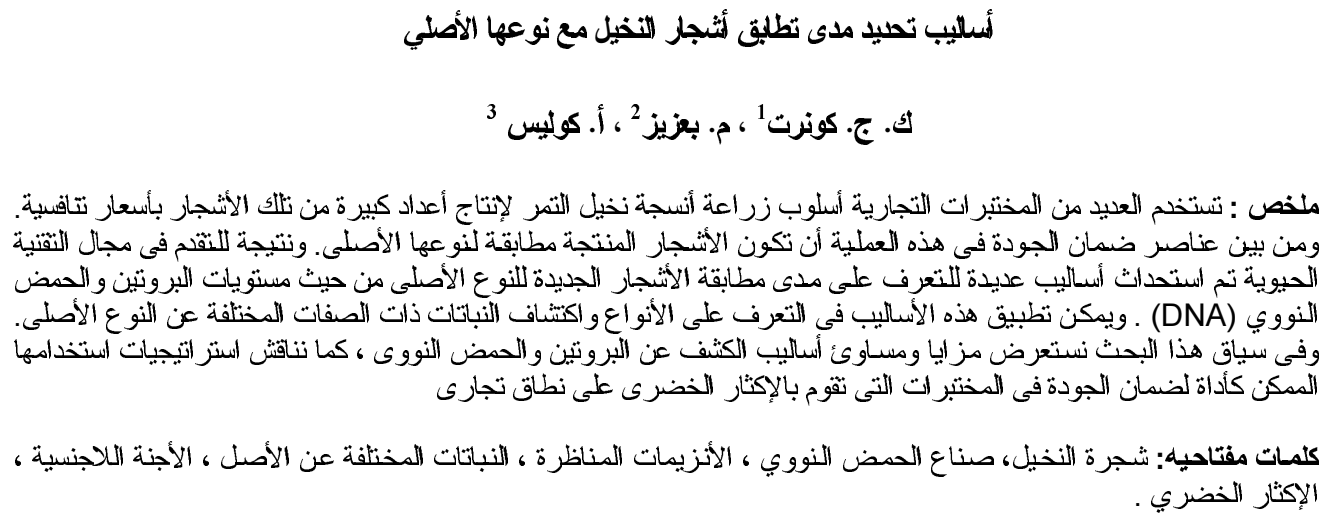

\section{How are date palms produced?}

Date palms can be propagated via seeds, vegetatively propagated via offshoots or via mass production in a sterile artificial laboratory environment using in vitro techniques. Vegetative propagation via offshoots derived from the axillary buds of the palm tree has been traditionally used as the main process for plant production. Unfortunately, this traditional procedure is limited by both the numbers of offshoots produced from a superior selected plant and the development of useful offshoots from a single plant, which occurs only during the juvenile phase of the palm's life. Offshoots of cultivars in high demand, therefore, not meet the market demand. This severely affects re-plantation programs, which are aimed to compensate for example plant losses caused by the Bayoud disease. Modern multiplication tools are consequently required to satisfy market demands (Moursy and Saker, 1998). In vitro production using either the process of somatic embryogenesis or organogenesis has been established in recent years as a routine procedure in several commercial laboratories to produce large numbers of date palm plants at a competitive cost. Since several thousands of plants can be produced from a single date palm mother plant by these techniques, in vitro production 


\section{K. J. Kunert et al.}

is currently the most promising tool to obtain sufficient plant material of high quality to overcome offshoot shortage.

Most commercial companies carry out micropropagation production of date palm via somatic embryogenesis, also called asexual embryogenesis. In this process, embryo-like structures, called somatic embryos, are produced from an explant, which can be somatic cells, tissues or organs derived from a single mother plant. Somatic embryos germinate like normal seed-derived embryos and produce, independently of season, phenotypically normal plants. In theory, these plants should be genetically homogeneous and identical to the mother plant. Somatic embryogenesis is currently the most efficient technique regarding rates of multiplication and production and, therefore, commercially attractive to completely replace traditional vegetative propagation practices.

Producers of date palms via somatic embryogenesis have recently become interested in an alternate process of in vitro production using organogenesis where explants are taken from selected parts of the plant and shoot formation is initiated on an appropriate culture medium. This process is supposedly easier to manage and might also lower the risk of plant off-type production. Especially organogenesis from male and female date palm inflorescences may offer a new possibility for mass multiplication complementing current production via somatic embryogenesis. The use of such mature inflorescences simplifies the technique and has the advantage that collection does not affect the mother plant (Loutfi and Chlyah, 1998).

\section{What are risks in date palm microprogation?}

The date palm micropropagation process, like other large-scale commercial plant production processes, carries a number of risks. Off-types, i.e. non true-to-type and genetically not identical to the mother plant, may be among the resulting plants. They simply can be the result of hardening errors and not originate from a change in the genetic make up of the plant. Plant off-types where the genetic make up has been likely changed might be produced via the application of excessive plant multiplication cycles in the presence of a plant growth regulator to obtain a maximal economically viable number of plants from a single mother plant. The application of a high concentration of a plant growth regulator to initiate the in vitro production process might also be a cause for plant off-type production.

The in vitro production of date palm via somatic embryogenesis requires the application of a relatively high concentration of an auxin-type plant growth regulator, such as 2.4-dichlorophenoxy acetic acid $(2,4-\mathrm{D})$ or 1-naphtaleneacetic acid (NAA), for process initiation (Tisserat, 1979; Bhaskaran and Smith, 1995). However, these auxins are known to be associated with genetic instability in plants, a phenomenon called somaclonal variation (Karp, 1989; Phillips et al., 1994; Cullis, 1999). Although somaclonal variation can be used as a source for variation to obtain superior clones it can be also a very serious problem in the plant tissue culture industry resulting in the production of undesirable plant off-types (Karp, 1993; Cassells et al., 1999). For example, plant off-types with a longer flower development time were found in higher frequency among certain oil palm lines derived from somatic embryos after a prolonged culturing time (Corley et al., 1986). The basis of somaclonal variation at the DNA level, i.e. the change in the structure of DNA (deoxyribonucleic acid), is still not well understood and is currently subject of investigation in several academic institutions. 
Accumulating evidence points towards a labile DNA portion of the plant genome that can be modulated when the cells undergo the stressful tissue culture process in the presence of plant growth regulators (Cullis, 1992; Cullis and Kunert, 2000; Sala et al., 1999).

However, it can be sometimes difficult to distinguish such permanent somaclonal changes from transient epigenetic changes. Such epigenetic changes might include transient expressions or modifications of a certain plant trait. But in contrast to somaclonal changes, this trait is not passed to their offspring through the sexual cycle or might also completely disappear during plant maturation. Epigenetic changes are often manifested after an exposure of plant material to a stressful condition and may be due to DNA amplification, DNA methylation, or activation of transposable elements (Brar and Jain, 1998).

Isolated reports about tissue culturederived plant off-types in date palm are controversial. Djerbi (2000) recently reported the abnormal fruiting of date palms derived from somatic embryogenesis. Abnormalities were specifically found for the cultivar Barhee, where pollinated bunches of more than 100000 date palms planted in the beginning and middle of the 1990s in the Kingdom of Saudi Arabia showed 80 to $100 \%$ of parthenocarpic fruits sometimes with the development of more than 3 carpels. Lack of pollination as the major abnormality in somatic embryogenesis-derived plants of the cultivar Barhee was also reported by McCubbin et al. (2000) after carrying out a survey in Southern Africa among farmers and companies regarding the appearance of plant off-types in date plantations. However, there is no indication yet that these tissue culturederived plants are pollination off-types based on changes in the DNA composition or have rather been derived from application of nonoptimal culture practices. These reports are also in contrast to the findings by Smith and
Ansley (1995) and Al-Ghamdi (1996) investigating the field performance of tissue culture-derived plants. Smith and Ansley (1995) found that somatic embryogenesisderived Barhee plants had no obvious abnormalities producing fruits of commercial quality indistinguishable from fruits of plants, which had originated from offshoots. AlGhamdi (1996) also observed no significant difference in flowering and fruit setting when the two cultivars Thoory and Zahdi were investigated. Abnormalities such as leaves variegation, seedless fruit, broader leaves, different spine structure, bending of stem and compact growth seem to be almost insignificant as types of variation (McCubbin et al., 2000).

\section{Why is a plant identification system important?}

Considerable investment into date palms that are discovered after several years to be non true-to-type has severe financial implications for both the grower and the commercial producer of date palm plants. It is therefore vital that a commercial producer can assure growers of the identity of the plants that they are purchasing. This requires the application of appropriate quality assurance tests to ensure both the true-to-typeness of a cultivar with the detection of phenotypic uniformity and agronomic performance.

The point at which plant off-types, may become a commercial liability, is, however, difficult to predict. Typically, the problem might be identified in the nursery or, more unfortunately, only in the field, when plants exhibit undesirable traits. For date palm, these undesirable traits may not be apparent for several years until fruit development occurs. Undetected plant off-types might finally turn out being extremely expensive for a commercial producer. Whatever investment has been made into that batch of plants containing an unacceptable number of plant off-types is lost. Further, when only detected in the field, the 


\section{K. J. Kunert et al.}

grower might request the complete replacement of plants, and/or the grower might seek compensation for the lost production. Either or both actions could ruin a small commercial producer. In addition, the existing market share may be lost to competitors in case the producer has been identified as supplying underperforming plant off-types of different quality. Being able to identify a cultivar correctly and to detect plant off-types as early as possible would save the investment, the time and money lost in producing that batch of plants, and the loss of the company's market share.

Implementation of a diagnostic marker as a quality assurance tool into the date palm production process would, therefore, have the following benefits:

- To identify date cultivars irrespective of any clear morphological characteristics for differentiation.

- To optimize tissue culture conditions without the fear of the possible concomitant increase in mutation rates.

- To quantify correctly the proportion of specific plant off-types in any population of produced plants.

Currently, a range of different approaches is available for detecting such plant off-types. The available test methods differ, however, in their sensitivity, technical complexity, ease of use, and stage at which they can be applied. However, we should always be aware that highly discriminatory profiling methods by using very sensitive molecular techniques ease the finding of minor genetic differences and increase genetic uniformity.

\section{Which diagnostic marker should be used to detect plant off-types?}

\section{Morphological identification}

Identification by morphological characters represents the easiest and least complex technique (Hussain and El-Zeid, 1978). The technique is carried out especially in small tissue culture companies as the only quality assurance procedure because of its simplicity and avoidance of an expensive analytical laboratory setup. In morphological identification, an experienced examiner identifies plant variants, often subjectively, predominantly in the nursery via description and visual monitoring of easily detectable plant characteristics, such as form and structure. Unfortunately, these characteristics may vary widely with the environment and the growth stage of the plant. Some characteristics, however, which change through somaclonal variation, are obvious once plants are established in the nursery. This includes a significantly changed plant structure or leaf discoloration and deformation.

Correct identification of many date palm cultivars is usually not possible until fruits are produced and frequently requires a large set of phenotypic data that are often difficult to assess and sometimes variable due to environmental influences (Sedra et al., 1998). Further, performance characteristics, such as pollination potential, yield potential, fruit quality or disease susceptibility, are still hidden in the juvenile stage of the date palm and are only expressed in the mature stage after several years of plant development. Overall, this makes morphological characterization, although economically attractive, largely useless for date palm and does not allow either correct cultivar identification or the detection of plant offtypes at the juvenile stage.

\section{Molecular markers}

Since morphological identification of off-types is unreliable at the juvenile stage of the date palm, a different type of marker is required at this plant development stage for cultivar identification and the possible 
detection of plant off-types. In contrast to morphological characters, molecular markers describe the internal make-up of a plant and identify the variance in either the production of a plant protein, which are expressed from certain regions of the DNA, or the total composition of DNA. Figure (1) outlines the general process for plant identification by either protein or DNA analysis. However, the application of molecular markers using electrophoretic techniques is more complex than relying on morphological characters, and requires skilled personnel as well as an analytical laboratory facility.

\section{Protein and DNA Analysis}

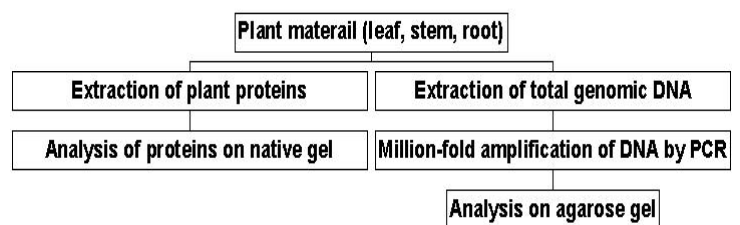

Figure 1. A general outline of the steps involved in plant identification by either protein or DNA analysis. Proteins are analyzed as isozymes on a native gel whereas DNA is analyzed on an agarose gel after DNA amplification by the polymerase chain reaction (PCR) using specific DNA primers.

\section{Protein markers}

Proteins have been used for many years as molecular markers, predominantly in academic laboratories, for plant identification (Kephart, 1990). Proteins are analyzed as isozymes, which are different molecular forms of a protein actively controlling identical biochemical processes of a living cell. Isozymes are separated in an electrical field supported in a polyacrylamide or starch matrix. A characteristic pattern of different isozyme bands called an "isozyme fingerprint" (Figure 2), is visualized after staining. A difference between isozyme fingerprints derived from two types of plants is further called a "polymorphism". Isozyme analysis has the clear advantage over DNAbased markers, of relative efficiency and cost effectiveness.

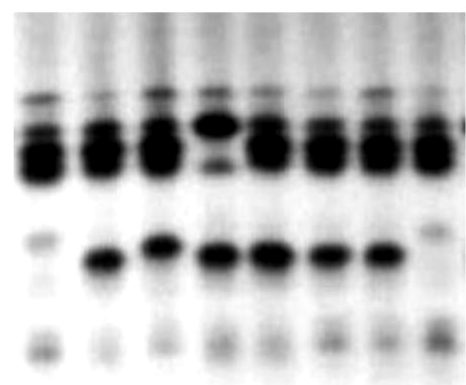

Figure 2. A typical isozyme fingerprint of date palm esterases showing the expression of isozymes of the enzyme esterase in a number of date palm cultivars. Cultivars are hence identified by their typical expression pattern (Baaziz, unpublished).

Several research groups have applied isozymes as descriptive markers in date palm to distinguish between cultivars (Torres and Tisserat 1980; Jasmin Aljibouri; 2000), to screen for Bayoud-resistant cultivars (Baaziz and Saaidi, 1988; Baaziz, 1989; Bendiab et al., 1993), to detect plant off-types from micropropagation (Salman et al., 1988; Saker et al., 2000), to carry out population studies (Bendiab et al., 1998) and to characterize calli and somatic embryos of date palm (Baaziz et al., 1994). Enzymes most commonly measured are esterase (EST), glutamate oxaloacetate transaminase (GOT), endopeptidase (ENP), alcolhol dehydrogenase $(\mathrm{ADH})$, peroxidase (PER) polyphenol oxidase (POD) and also phosphoglucose isomerase (PGI), 


\section{K. J. Kunert et al.}

phosphoglucose mutase (PGM) and leucine [cytosol] aminopeptidase (LAP).

Isozyme analysis has been applied to date palm cultivar identification. In a first report almost 20 years ago, Torres and Tisserat (1980) outlined that leaf isozymes can be used as genetic markers in date palm identification. By screening different enzymes the high-demanded cultivars Medjool and Barhee could be differentiated by PGI. However, no differentiation could be made between the five cultivars Barhee, Dayri, Deglet Noor, Khadrawy and Medjool with the enzymes EST and ADH. The general potential for isozyme analysis to identify cultivars has also been demonstrated in several studies. This includes a study to find relationships between isozyme profiles and resistance to the Bayoud disease (Baaziz and Saaidi, 1988; Baaziz, 1989; Bendiab et al., 1993), to determine the date palm cultivar composition of Moroccan palm groves and to differentiate calli and somatic embryos of two Moroccan date palm cultivars with the aim to find biochemical markers for somatic embryo development (Baaziz et al., 1994). Bendiab et al. (1998) were successful in differentiating 28 reputed cultivars by isozyme analysis.

Unfortunately, no evidence has been reported that such protein markers can differentiate between individual plants of the same cultivar to detect plant off-types caused by somaclonal variation. Salman et al. (1988) reported that regenerated plants of four date palm cultivars derived from callus cultures showed similar banding patterns within cultivars for the enzymes EST, GOT and cytosolic LAP on polyacrylamide electrophoresis but variation between the different cultivars tested was observed. This result was recently confirmed by Saker et al. (2000) analyzing PER, POD and GOT. Similar banding patterns for PER and GOT were detected in all analyzed plants.
However, variations in activity levels of the three enzymes investigated were found as well as POD isomers in 6-12 month old cultures.

Isozyme analysis, although easy to apply, has several general drawbacks. These include the dependence of isozyme expression on environmental conditions, the organ-specific presence of an isozyme and the often-limited amount of detectable polymorphism. Despite these drawbacks, protein markers have a demonstrated potential in date palm cultivar identification and analysis of laboratory or nursery-derived plants. However, isozyme analysis, which lacks a direct assessment of the genomic variation at the DNA level, and as such is inadequate to detect most of the offtypes that are derived from tissue culture and could comprise the bulk of somaclonal variants.

\section{DNA markers}

Commercial producers cannot ignore the advancements made in plant biotechnology including the application of DNA-based markers for quality assurance. In contrast to "isozyme fingerprinting" DNA-based systems have the general advantage that the DNA content of a cell is independent of environmental conditions, organ specificity or growth stage. Each cell of a living individual contains DNA as genetic material, and the DNA determines the individual characteristics via the control of protein synthesis in the cell. However, except for some major crops like maize, DNA-based identification techniques for plants are not well advanced, when compared to techniques developed for humans or animals. DNA-based tests for date palm identification include techniques such as RAPD (Random Amplified Polymorphic DNA), RFLP (Restriction Fragment Length Polymorphism), AFLP (Amplification Fragment Length Polymorphism) and RDA 
(Representational Difference Analysis) (Powell et al., 1996; Cullis et al., 1999).

\section{$\boldsymbol{R A P D}$}

The characterization of a DNA sample by Random Amplified Polymorphic DNA or RAPD analysis, which is often referred to as DNA "fingerprinting", has attracted considerable attention in the last ten years. RAPD is possibly the simplest test of all recently applied DNA-based tests for date palm identification. The RAPD technique consists of the production of duplicate of segments of plant DNA and these DNA segments are several million-fold amplified in a reaction called Polymerase Chain Reaction (PCR). To duplicate the plant DNA, sets of very short nucleotides, called primers that consist of the basic building blocks of DNA, are required. These primers, which bind selectively to the master-copy of plant DNA, are commercially available from several biotechnology companies. A thermostable enzyme, called Taq DNA polymerase, which carries out rapid temperature fluctuation cycles, is necessary for the duplication process and consequently several million-fold amplification of DNA segments are obtained. Finally, amplified DNA segments are separated on either agarose or polyacrylamide gels and visualized by staining. The detected polymorphism between individual plants may result from either a DNA sequence difference in the binding site for the primer on the plant DNA or a deletion of parts of the plant DNA. As shown in Figure 3, both processes are visible as the absence of a particular RAPD band after separation on a gel system, which allows the differentiation of cultivars.

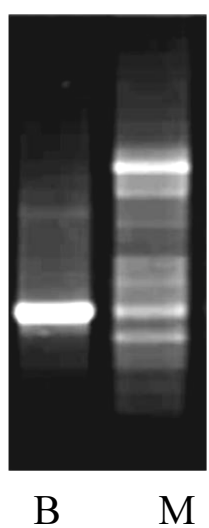

Figure 3. A typical date palm RAPD fingerprint showing different DNA products after DNA amplification of part of the genome in the cultivars Medjool (M) and Barhee (B). Cultivars are identified by the typical DNA amplification profile using a specific primer in a PCR reaction for DNA amplification.

Since RAPD analysis requires no special equipment apart from a high quality thermocycler and a gel assembly, this technique has the advantage of being simple, rapid and requiring only a little amount of isolated DNA, normally from a plant leaf. Virtually unlimited numbers of different RADPs can be obtained by simply changing a primer without changing other experimental conditions. After optimization of the technique, a semi-qualified person can theoretically carry out RAPD analysis in a commercial laboratory on a routine basis.

In a first report about date palm cultivar identification with RAPD, Corniquel and Mercier (1994) found polymorphisms among the cultivars Barhee, Deglet Noor and Medjool after total DNA extraction from offshoot leaves of different individuals and amplification of DNA segments with commercially available random primers OPE01, OPB05 and OPE06 purchased from Operon Technologies Inc. (USA). They also indicated that RAPD enabled to differentiate, via changed banding patterns, between individuals of the same cultivar. 


\section{K. J. Kunert et al.}

RAPD as a molecular marker system has also been successfully applied in cultivar identification. After pre-screening of 123 DNA primers on four genotypes, 19 selected primers revealed polymorphisms and gave reproducible results regarding genetic variation among 43 date palm accessions, including 37 accessions from Morocco and 6 cultivars from Iraq and Tunisia (Sedra et al., 1998). All 43 analyzed genotypes were distinguishable by their band patterns. To detect somaclonal variation, Saker et al. (2000) analyzed tissue culture-derived date palm plants and showed that genetic variations occurred in approximately $4 \%$ of the analyzed plants representing 70 plant regenerants. As also found for POD isozyme patterns, polymorphic bands in RAPD profiles were only detected in 6-12 months old cultures.

RAPD analysis is normally found to be easy to perform but has the major disadvantage that reproducibility is difficult to achieve between different laboratories and often even between different people in the same laboratory (Jones et al., 1997). Any diagnostic laboratory, which intends to use RAPD analysis as a quality control tool, has, therefore, firstly to ensure constant detection of identical DNA amplification products by several-fold repeated experiments preferably by different people. Elimination of possible variation in both DNA concentration and purity and assurance of consistent reaction conditions maybe a first step to overcome difficulties with assay reproducibility. There are further several reports on the importance of Taq polymerase and the thermocycler used in the PCR reaction for RAPDs and variability in RAPD profiles due to the use of different brands of both. For example, different brands of DNA Taq polymerase amplify differently, which result in varying profiles of DNA amplification products. Skroch and Nienhaus (1995) examined the impact of this irreproducibility on the scoring of RAPDs. When expressed as the percentage of RAPD bands scored that were also scored in replicate data, only $75 \%$ reproducibility was obtained for 50 RAPD primers. If RAPD is envisaged as a general technique for date palm identification, a major task will be to ensure consistent reaction conditions. These conditions have to be applicable in different testing laboratories with a similar result preferably using thermocyclers of identical quality to maintain consistency in the thermal profile during DNA amplification and the use of a DNA Taq polymerase of identical quality.

\section{RFLP}

Restriction Fragment Length Polymorphism (RFLP) can be analyzed by the combination of restriction enzyme digestion followed by hybridization of the fragments produced with a DNA probe. Unfortunately, this widely used process requires both large amounts of DNA and the isolation of informative probes that yield differences between the sources of the DNA. The most frequent sources of probes for RFLP analysis include cDNA clones and microsatellites. The use of RFLP in the traditional form of hybridization of labeled probes to filter-bound DNA has been replaced by PCR-based techniques. This is because of the labor-intensive nature of identifying suitable probes as well as the extended time needed to undertake the experiments.

There are no instances where a traditional RFLP analysis is being used for routine cultivar identification. For date palm, the technical aspects for plant identification using RFLP are in place. Both the isolation of DNA from leaf samples (Aitchitt et al., 1993; Ouenzar et al., 1998) and the isolation of cDNA clones that have utility as probes for discriminating between cultivars have 
been described (Corniquel and Mercier, 1994 and 1997). But there are only a few of these probes available yet.

\section{AFLP}

Amplification Fragment Length Polymorphism (AFLP) analysis is a combination of the characteristics of RFLP and RAPD markers, in that they are a result of restriction site polymorphisms that are detected by amplification using specific adapters with PCR amplification. The method generates a large number of bands that serve as the markers for fingerprint and trait analysis.

AFLP have been used for cultivar identification in many species. They have also been shown to be useful in date palms (Lacaze et al., 2000). Twenty primer combinations were tested to identify those combinations giving the maximum discrimination between two varieties of diverse, geographical origin (Khalas and Medjool). Two primer combinations, giving a total of 45 polymorphic bands, were selected for a more detailed study. A clear discrimination was obtained between all varieties tested using the selected primer combinations. This technique, with the two identified primers, was also used to confirm variety status of tissue culture-derived date palms. Representative DNA samples from Barhee and Khalas production lines were subjected to AFLP fingerprinting analysis and comparison with the variety standard DNA samples. This analysis indicated that all tissue culture lines were identical to the variety standards. However, the primer combinations only sample a very small portion of the genome. Therefore, any genomic variation could easily have been missed.

\section{Microsatellites}

Microsatellites are small arrays (typically $<100 \mathrm{bp}$ ) of simple di- and tri-nucleotide repeats (Scribner and Pearce, 2000). These arrays vary in length and can be highly polymorphic. They suffer from a similar drawback as RFLP, namely, they need to be isolated and then to be characterized. Normally, screening genomic libraries with the labeled repeat of interest identifies microsatellites. The region of the clone containing the microsatellite is then sequenced and PCR primers designed within the unique flanking regions spanning the satellite sequence. These primers then generate a sequenced-tagged site. The characteristic length of the amplification product can then be used as a marker. The identification of hyper-variable microsatellites, with multiple alleles, that varied between all the common date palm varieties would provide a series of markers that could unambiguously identify these varieties. Such a set of markers would take about 12 months to develop in an experienced laboratory. Although microsatellites might have a great potential, no such satellite markers have yet been described in date palms. In fact there is only currently a strong emphasis to develop such markers for plants (Scribner and Pearce. 2000). In our opinion, the development of a set of microsatellite markers would be useful for date palm variety identification. However, there is no evidence that such sequences are present in the highly variable regions of the genome and so may not be useful in monitoring somaclonal variation.

\section{$R D A$}

Representational Difference Analysis (RDA) was originally developed to isolate the sequence differences between the 


\section{K. J. Kunert et al.}

genomes of cancer and normal cells. In principle, RDA can be used to derive probes for genomic losses, rearrangements, amplifications, point mutations and pathogenic organisms found within any organisms (Lisitsyn et al., 1993). The technique combines representation, subtractive hybridization, and kinetic enrichment (Figure 4). Representation means a production of the sub-population of DNA fragments derived from a given DNA population such that the sequence complexity of the sub-population is lower than the sequence complexity of the initial DNA. Representations that reduce complexity at least ten-fold over the complexity of genome of higher organisms with genomes as complex as humans are generally required for the success of these subsequent steps. Subtractive hybridization can be explained as eliminating similar sequences by hybridization between two representations and obtaining unique sequences present in only one of the representations. Kinetic enrichment is based on the second order kinetics of DNA re-annealing. The rate of formation of double stranded DNA is higher for DNA species of higher concentration. The first round of RDA is mainly dependent on subtractive enrichment, but subsequent rounds do heavily rely on kinetic enrichment. In RDA, kinetic enrichment and subtractive enrichment are combined in a single step called hybridization/amplification.

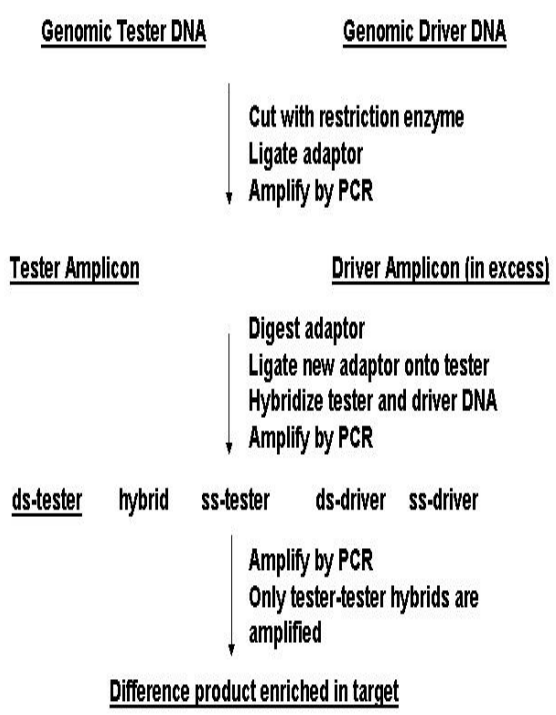

Figure 4. A general outline of the steps involved in the RDA technique to identify genome differences between two types of plants. Molecular techniques applied include genomic DNA digestion with a restriction enzyme, ligation of oligonucleotide adaptors to digested DNA, enrichment of DNA sequences by PCR and subtraction of DNA sequences by DNA-DNA hybridization. Final DNA difference products unique to one type of plant are cloned and the DNA sequence analyzed. Tester and driver DNA represents genomic DNA from two types of plants; ds and ss represent double and single-stranded DNA, respectively. Only double-stranded tester-DNA (ds-tester) is finally amplified as difference product.

The RDA procedure is carried out in two stages. The first comprises the preparation of representations for driver and tester DNAs, during which restriction endonuclease fragments are ligated to oligonucleotide adapters and amplified by PCR. Since PCR amplifies smaller fragments more efficiently, the representation called amplicons is now populated with smaller fragments from the restriction endonuclease digest. The second stage is comprised of the reiterative hybridization / amplification step, prior to which, only tester (target) molecules are fitted with a new pair of defined 
oligonucleotides at their 5' ends. After reannealing tester and driver, the mixture of molecules is treated with DNA polymerase. This adds the complement of the defined oligonucleotides to both 3 ' ends of only self re-annealed tester DNA fragments. When the defined oligonucleotide is used as primer in PCR of the mixture, only these molecules can participate in exponential amplification. RDA techniques have also been used with cDNA to identify the differentially expressed genes in animals and plants (Hubank and Schatz, 1994; Li et al., 1999).

In order to identify variety-specific markers, RDA can be modified to select DNA sequences, which are present in the representation from the desired variety and absent from the representation of all of the other varieties. RDA has been applied to identify differences between Barhee and Medjool (Kunert et al, 2000, Vorster et al., 2002). Reciprocal subtractions using the enzyme BamHI for developing the representation were performed with Medjool as driver and Barhee as tester in one, and with Barhee as driver and Medjool as tester in the other. The first difference product that has been characterized appears to represent a hyper-variable region and has some potential for determining varietal variation as well as tissue culture induced variation.

The application of RDA to pooled samples holds the promise of developing markers that are specific to each individual variety. All of the other techniques described rely on a profile that is a particular pattern derived from a series of markers that is distinctive for each particular variety. The use of a combined sample approach should result in the development of markers that are specific to a particular variety. Such plus/minus markers will be useful in both small operations to identify varieties as well as for the development of microchip diagnostics.

The use of RDA for developing markers for culture-induced variation is unproven in date palm. However, data from banana has indicated that it is likely that the approach will be fruitful (Cullis et al., 1999; Cullis and Kunert, 2000). The particular advantage of RDA in this context is the ability to screen a much greater fraction of the total genome in a single experiment.

\section{Microchip technology}

The DNA fingerprinting world is excited about the advent of DNA chip technology, which might be exploited as the ultimate DNA fingerprinting application (Kunert et al., 2002). The procedure involves synthesizing probes, attaching them to solid surfaces to fabricate microchips. Single-stranded fluorescentlabeled genomic sequences are then hybridized to these microchips and pattern is determined by reading the micro-arrays. The microarray technology is still in its infancy and very expensive, but there is a growing sense that in the future genome analysis will be performed on " microchips". Application of the 'DNA chip' technology specifically in the traditional plant tissue culture industry, represented by small to medium-seized companies will, however, depend greatly on whether costeffective microarray technology can be provided in the future.

\section{Why is the implementation of a diagnostic marker still a slow process?}

Unfortunately, there is a school of thought originating from traditional plant breeding which favors that any discrimination should be based on expressed characters, ignoring the addition of molecular characteristics as complementary to support morphological characters. Besides gaining recognition as a tool for plant variety protection, new DNAbased technologies have still to prove their reliability and cost-effectiveness and 


\section{K. J. Kunert et al.}

demonstrate that they can be more effective than traditional methods (Archak, 2000).

Mainly due to lack of both the clear identification of plant off-types and detailed research efforts, none of the diagnostic marker techniques so far applied for date palm has fulfilled all of the following demands:

- Easily applicable and inexpensive.

- Easily differentiating date palm cultivars.

- Applicable to in vitro material and mature plants.

- Able to detect both genetic and epigenetic variation.

- Able to be used to predict plant quality.

- Able to predict the proportion of plant offtypes.

The current companies involved in date palm production are predominantly entrepreneur-type small to medium-seized production facilities without significant service or Research and Development facilities. Such companies can hardly afford to pay for sophisticated technologies or to implement complex diagnostic techniques into their business to screen a great number of plants. Cost will therefore be the main factor in the adoption of any routine quality assurance screening. Currently, a reasonably priced and easily applicable diagnostic tool, which can do both cultivar identification and detection of plant off-types, does not exist. As long as such a diagnostic tool is not available, isozyme analysis and RAPD in combination with morphological screening offer, despite their major limitations of reproducibility and expression of performance characteristics, the only costeffective and easily applicable tool for date palm identification.

Finally, it is also not entirely clear what economic impact plant off-types actually have on both the producer and grower.
Besides recent indications of pollination problems, date palm seems to be genetically quite stable in comparison, for example, to other monocotyledonous crops (Linacero and Vazquez, 1993) and reports about plant offtypes in date palm are still rather sporadic. It is, therefore, understandable that specifically smaller commercial producers are reluctant to implement a costly new technology into their operation as long as there is no obvious benefit to enhance their commercial operation efficiency.

Among the challenges for date palm micropropagation is to develop a more robust and cost-effective DNA-based detection technique, which has to be standardized for both cultivar identification and detection of somaclonal variants. Such a technique must be affordable and be easily applied by commercial producers. In addition, acceptance of "DNA fingerprints" as "signatures" in legal cases will depend on the development of data to convince legal authorities and policy makers of its utility. Current techniques have the disadvantage in that they are either not robust (isozyme analysis and RAPD), expensive when applied to a great number of plants (RFLP and AFLP), have not clearly demonstrated their potential (RDA) or have not been even tried (microsatellites and DNA chip technology). In addition, under-performing plant off-types have only recently been detected in the field; therefore none of current detection techniques have demonstrated the ability to detect such plant off-types.

Significant progress, however, in the improvement and evaluation of the current and possible new detection techniques will only be made with the help of a commercial service laboratory having a focus on the development and implementation of molecular diagnostics. In that, the academic world can only play a supportive role. Scientists in the academic environment often do not understand that 
commercial imperatives demand far more than just technological advances. They are continuously challenged to update themselves on the latest scientific developments and they are constantly urged to try everything that is new. Commercial laboratories, however, experienced in the development of molecular diagnostic techniques, have rarely focused on minor crops, such as date palm. These crops are normally produced in a relatively small number possibly demanding only several hundreds of quality assurance tests per year. This would hardly justify any developmental work, which might easily cost several hundreds of thousand SUS. A fast and significant progress in the development and business implementation of a detection technique might only be achieved in case that the development cost can be recovered by either producers paying a substantial license fee for a detection technique or by gaining financial support of an international funding agency.

\section{References}

Aitchitt M., C. C. Ainsworth, and M. Thangavelu. 1993. A rapid and efficient method for the extraction of total DNA from mature leaves of the date palm (Phoenix dactylifera L.). Plant Molecular Biology Reporter 11: 317-319.

Archak S. 2000. Plant DNA fingerprinting: An overview. AgBiotechNet. 2: April issue.

Al-Ghamdi A.S. 1996. Field evaluation of date palm (Phoenix dactylifera L.) cultivars produced through tissue culture techniques. 4. Fruit chemical properties. Bulletin of Faculty of Agriculture, University of Cairo. 47: 167-177.

Baaziz M. and M. Saaidi. 1988. Preliminary identification of date palm cultivars by esterase isoenzymes and peroxidase activities. Canadian Journal of Botany. 66: 89-93.

Baaziz M. 1989. The activity and preliminary characterization of peroxidases in leaves of cultivars of date palm, Phoenix dactylifera L. New Phytologist 111: 403-411.

Baaziz M., F. Aissam, Z. Brakez, Bendiab K., I. El Hadrami, and R. Cheikh. 1994. Electrophoretic patterns of acid soluble proteins and active isoforms of peroxidase and polyphenoloxidase typifying calli and somatic embryos of two reputed date palm cultivars in Morocco. Euphytica 76: 159-168.

Bhaskaran S. and R. H. Smith. 1995. Somatic embryogenesis in date palm (Phoenix dactylifera L.). In: S. Jain; P. Gupta, and R. Newton (eds.). Somatic embryogenesis in woody plants. Kluwer Academic Publishers, The Netherlands. pp. 461-470.

Bendiab K., M. Baaziz, Z. Brakez, and M. H. Sedra. 1993. Correlation of isoenzyme polymorphism and Bayoud-disease resistance in date palm cultivars and progeny. Euphytica 65: 23-32.

Bendiab K., M. Baaziz, and K. Majourhat. 1998. Preliminary date palm cultivar composition of Moroccan palm groves as revealed by leaf isoenzyme phenotypes. Biochemical Systematics and Ecology 26: 71-82.

Brar D.S. and S. M. Jain. 1998. Somaclonal variation: mechanisms and applications in crop improvement. In: S.M. Jain, D.S. Brar, and B.S. Ahloowalia (eds.). Somaclonal variation and induced 


\section{K. J. Kunert et al.}

mutations in crop improvement. Kluwer Academic Publishers, Boston, USA. pp. 17-37.

Cassells A.C., S. M. Joyce, R. F. Curry, and T. F. McCarthy. 1999. Detection of economic variability in micropropagation. In: A. Altman, M. Ziv, and S. Izhar (eds.). Plant Biotechnology and in vitro Biology in the $21^{\text {st }}$ Century. Kluwer Academic Publishers, The Netherlands. pp. 241244.

Corley R.H.V., C. H. Lee, I. H. Law, and C. Y. Wong. 1986. Abnormal flower development in oil palm clones. Planter 62: 233-240.

Corniquel B. and L. Mercier. 1994. Date palm (Phoenix dactylifera L.) cultivar identification by RFLP and RAPD. Plant Science 101: 163-172.

Corniquel B. and L. Mercier. 1997. Identification of date palm (Phoenix dactyllifera L.) cultivars by RFLP: Partial characterization of a cDNA probe that contains a sequence encoding a zinc finger motif. International Journal of Plant Science 158:152-156.

Cullis C.A. 1992. The molecular biology of plant cells and cultures. In: M.W. Fowler and G.S. Warren (eds.). Plant Biotechnology. Pergamon Press, Oxford. pp. 19-32

Cullis C.A. 1999. Environmental Stress - a generator of adaptive variation. In: H.R. Lerner (ed.). Plant Adaptations to Stress Environments. Marcel Dekker, New York. pp. 149-160.
Cullis C. and K. J. Kunert. 2000. Isolation of tissue culture-induced polymorphisms in bananas by representational difference analysis. Acta Horticulturae, in press.

Cullis C., S. Rademan, and K. J. Kunert. 1999. Method for finding genetic markers of somaclonal variation. International publication number WO 99/53100.

Djerbi M. 2000. Abnormal fruiting of the date palm trees derived from tissue culture. Date Palm International Symposium. Windhoek, Namibia. 2225 February, 2000.

Hubank M. and D.G. Schatz. 1994. Identifying differences in mRNA expression by representational difference analysis of cDNA. Nucleic Acids Research 22: 5640-5648.

Hussain F. and A. El-Zeid. 1978. Studies on physical and chemical characteristics of date varieties of Saudi Arabia. Ministry of Agriculture and Water, Kingdom of Saudi Arabia.

Jasmin Aljibouri, A.M., M. S. Omar, and W. K. Al-Quadhy. 2000. Identification of date palm plantlets derived from tissue culture. Date Palm International Symposium. Windhoek, Namibia. 2225 February 2000.

Jones C.J., K. J. Edwards, S. Castaglione, M. O. Winfield, F. Sala, C. van de Wiel, G. Bredemeijer, B. Vosman, M. Matthes , A. Daly, R. Brettschneider, P. Bettini, M. Buiatti, E. Maestri, A. Malcevschi, N. Marmiroli, R. Aert, G. Volckaert, J. Rueda, R. Linacero, A. Vazquez, and A. Karp. 1997. Reproducibility testing of RAPD, AFLP and SSR markers in plants 
by a network of European laboratories. Molecular Breeding 3: 381-390.

Karp A. 1993. Are your plants normal? Genetic instability in regenerated and transgenic plants." Agro-Food-Industry Hi-Tech. May/June. PP. 7-12.

Karp A. 1989. Can genetic instability be controlled in plant tissue cultures? Newsletter of the International Association of Plant Tissue Culture 58: 2-11.

Kephart S.R. 1990. Starch gel electrophoresis of plant isozymes: A comparative analysis of techniques. American Journal of Botany. 77: 693712 .

Kunert K.J., J. Vorster, E. Bey, and C. A. Cullis 2000. Representational difference analysis as a DNA-based quality assurance procedure for date palm. micropropagation. Date Palm International Symposium. Windhoek, Namibia. 22-25 February 2000.

Kunert K.J., J. Vorster, C. Bester, and C. A. Cullis. 2002. DNA microchip technology in the plant tissue culture industry. In: Crop Biotechnology. K. Rajasekaran, T.J. Jacks, J.W. Finley (eds.). ACS Symposium Series 829. American Chemical Society, Washington DC. pp 86-96.

Lacaze P. and A. Brackpool. 2000. Molecular fingerprinting of date palm cultivars using AFLP. Date Palm International Symposium. Windhoek, Namibia. 22-25 February 2000.

Li J.H., H. S. Shao, and X. Q. Zheng. 1999. Rapid identification of tomato somaclonal variation with RAPD. Journal of Tropical and Subtropical Botany 7: 308-312.

Linacero R. and A. S. M. Vazquez. 1993. Somaclonal variation in rye. Mutation Research 302: 201-205.

Lisitsyn N., N. Lsistsyn, and M. Wigler. 1993. Cloning the differences between two complex genomes. Science 259: 946-950.

Loutfi K. and H. Chlyah. 1998. Vegetative multiplication of date palms from in vitro cultured inflorescences: effect of some growth regulator combinations and organogenetic potential of various cultivars. Agronomie 18 :573-580.

McCubbin M.J., J. van Staden, and A. Zaid. 2000. A Southern African survey conducted for off-types on date palms produced using somatic embryogenesis. Date Palm International Symposium. Windhoek, Namibia. 22-25 February 2000 .

Moursy H.A. and M. M. Saker. 1998. Date palm problems and the need for biotechnology. Bulletin of Faculty of Agriculture University of Cairo 49: 315330.

Ouenzar B., C. Hartmann, A. Rode, and Benslimane A. 1998. Date palm DNA mini-preparation without liquid nitrogen. Plant Molecular Biology Reporter 16: 263-269.

Phillips R.L., S. M. Kaeppler, and P. Olhoft. 1994. Genetic instability of plant tissue cultures: Breakdown of normal controls. Proceedings of the National Academy of Science USA 91: 5222-5226. 
K. J. Kunert et al.

Powell W., M. Morgante, C. Andre, M. Hanafey, J. Vogel, S. Tingey, and A. Rafalski. 1996. The comparison of RFLP, RAPD, AFLP, and SSR microsatellite markers for germplasm analysis. Molecular Breeding 2: 225238.

Saker M.M., S. A. Bekheet, H. S. Taha, A. S. Fahmy, and H. A. Moursy. 2000. Detection of somaclonal variations in tissue culture-derived date palm plants using isozyme analysis and RAPD fingerprints. Date Palm International Symposium. Windhoek, Namibia. 2225 February 2000.

Sala F., A. Arencibia, S. Castiglione, P. Christou, Y. Zheng, and Y. Han. 1999. Molecular and field analysis of somaclonal variation in transgenic plants. In: A. Altman, M Ziv, and S. Izhar (eds.). Plant Biotechnology and In Vitro Biology in the 21st Century. Kluwer Academic Press, The Netherlands. pp. 259-262.

Salman R.M., A. A. M. Al Jibouri, W. K. Al Quadhy, and M. S. Omar. 1988. Isozyme and chromosomal analyses of tissue culture derived date palms. Date Palm Journal 6: 401-411.

Scribner K. T. and J. M. Pearce. 2000. Microsatellites: evolutionary and methodological background and empirical applications at individual, population, and phylogenetic levels. Pages 235-271, in A. Baker, editor.
Molecular Methods in Ecology. Blackwell Science Limited, London, England.

Sedra M.H., P. Lashermes, P. Trouslot, M. C. Combes, and S. Hamon. 1998. Identification and genetic diversity analysis of date palm (Phoenix dactylifera L.) varieties from Morocco using RAPD markers. Euphytica 103: 75-82.

Skroch P. and J. Nienhaus. 1995. Impact of scoring error and reproducibility of RAPD data on RAPD based estimates of genetic distance. Theoretical Applied Genetics 91: 1086-1091.

Smith R.J. and J. S. Ansley. 1995. Field performance of tissue cultured date palms (Phoenix dactylifera) clonally produced by somatic embryogenesis. Principes 39: 47-52.

Tisserat B. 1979. Propagation of date palm (Phoenix dactylifera L.) in vitro. Journal of Experimental Botany 30: 1275-1283.

Torres A.M. and B. Tisserat. 1980. Leaf isozymes as genetic markers in date palms. American J. of Botany 67: 162167.

Vorster J.B., K. J. Kunert, and C. A. Cullis. 2002. Use of representational difference analysis for the characterization of sequence differences between date palm varieties. Plant Cell Reports 21: 271-275. 